\title{
Direitos do trabalho em disputa no STF: o papel dos procuradores do trabalho
}

\section{Labor rights in dispute in the STF: the role of labor prosecutors}

\author{
Karen Artur \\ Ligia Barros de Freitas
}

\begin{abstract}
Resumo
Por meio da abordagem histórico institucionalista, o objetivo deste artigo é tratar da atuação judicial dos procuradores do trabalho junto ao Supremo Tribunal Federal (STF), a qual é realizada por meio sua associação nacional (ANPT), apontando os argumentos utilizados e os constrangimentos e estímulos institucionais encontrados. Para tanto, levantamos e analisamos açóes judiciais promovidas no STF, nos temas centrais que têm movimentado a agenda institucional da ANPT. Como resultados, apresentamos uma atuação pautada na defesa de direitos e instituiçóes do trabalho e das políticas públicas relacionadas, as quais tratam de temas contestados por entidades de classe empresariais. Além disso, abordamos como as decisóes dos ministros do STF podem reforçar seu próprio poder de direcionar as políticas da área e também podem limitar as vozes institucionais que se aproximam das demandas da sociedade civil pela defesa dos direitos do trabalho.
\end{abstract}

\section{Palavras-chave}

Supremo Tribunal Federal; Procuradores do Trabalho; Direitos do Trabalho.

\section{Abstract}

Through the historical institutionalist approach, the aim of this article is to deal with the judicial action of labor prosecutors before the Supreme Federal Court (STF), which is carried out through its national association (ANPT), pointing out the arguments used and the constraints and institutional stimuli. Therefore, we raise and analyze judicial actions promoted in the STF, in the central themes that have moved the institutional agenda of ANPT. As results, we present an action based on the defense of labor rights and institutions and related public policies, which deal with issues challenged by business class entities. In addition, we discuss how the decisions of the STF ministers can strengthen their own power to direct the policies of the area and can also limit the institutional voices that approach the demands of the civil society for the defense of the labor rights.

\section{Keywords}

Brazilian Supreme Court; Labor Prosecutors; Labor Rights. 


\section{Introdução $^{1}$}

Ao longo da história jurídico-trabalhista, o STF foi importante arena de disputas, retificando ou modificando as decisões provindas da Justiça do Trabalho, especialmente do TST (ARTUR, 2012; FREITAS, 2012). Após a Constituição de 1988, os procuradores do trabalho, por meio do poder atribuído ao Ministério Público, como guardião dos interesses da sociedade, começam a se valer dessa arena institucional do STF na defesa de direitos trabalhistas e políticas públicas relacionadas.

O objetivo deste artigo é analisar a ação estratégica dos procuradores do trabalho junto ao STF, a qual é realizada por meio da atuação da ANPT, apontando os argumentos utilizados e os constrangimentos e estímulos institucionais encontrados.

Metodologicamente, este trabalho guiou-se pelas pesquisas feitas no Brasil que se valem das abordagens do institucionalismo histórico, dentre elas, a de Koerner (2012) que tem apresentado que as normas jurídicas não estão simplesmente à disposição de seus membros, mas sua utilização envolve a tradução sob a forma de elementos jurídicos da estruturação social do direito, nos quais estão presentes a tradição jurídica, as relaçôes estratégicas e a as interaçôes com os demais agentes políticos e sociais.

Para mapear os temas de atuação do MPT levados ao Supremo Tribunal Federal, por meio de sua associação nacional, foram levantadas junto à Corte as ações judiciais nas quais a ANPT figurasse como amicus curiae, parte ou interessada. Selecionamos, então, as açôes referentes à defesa do direito do trabalho, excluindo temas de interesses exclusivos de seus associados. Em seu conjunto, essas ações versam sobre questôes relativas ao meio ambiente do trabalho, à terceirizaçáo e ao combate ao trabalho em condições análogas a de escravo. No material colhido, foram analisadas a petição inicial; os fundamentos da decisão do relator sobre a admissibilidade do amicus curiae; os argumentos da ANPT nessas ações e os votos existentes.

A partir das notícias do STF, também realizamos o levantamento de ações judiciais promovidas pela ANPT, nos temas mencionados, que não foram aceitas pela Corte. Assim, no total, foram analisadas 10 açôes apresentadas até o ano de 2015. Nesse conjunto, a ANPT atua como propositora em uma ação; em cinco, como amicus curiae (ver Quadro 1, adiante) e em três teve negada a sua participação.

\footnotetext{
${ }^{1}$ Este artigo é uma versão de trabalho apresentado no congresso da ALACIP, em 2017.
} 
Dessas negativas, duas se deram em pedidos como amicus curiae em açôes diretas de inconstitucionalidade sobre o amianto e uma em recurso com repercussão geral referente à terceirização. Uma das ações ainda estava sem decisão da relatora, qual seja, a que a ANPT entrou com o pedido como amicus curiae para defender a constitucionalidade da lista das empresas com trabalho escravo.

Nas açôes que foram aceitas, a associação tem se valido da cultura jurídica constitucional que afirma que os valores sociais do trabalho e da livre iniciativa devem ter suas dimensôes realizadas conforme os ditames da justiça social, propondo, também, que a legislaçáo seja interpretada a partir de convençóes internacionais do trabalho e pactos de direitos humanos (ver Quadro 2, adiante). Além disso, em uma lógica de aproximação com a sociedade civil fundamentam suas posiçôes nos argumentos dos atores sociais que defendem o direito do trabalho, além de sua própria experiência judicial. Entendemos que essa associação busca legitimar sua atuação política e jurídica por meio de fundamentação discursiva que se apoia na esfera pública, de modo que tal atuação não é exclusivamente pautada em seus interesses corporativos, mas em sua visão da missão constitucional de defesa dos interesses sociais, construída na relação com os demais atores.

Além dessa introdução e das considerações finais, este artigo conta com outras seções que tratam da análise da arena trabalhista em diálogo com a literatura sobre o poder judicial e também dos temas da atuação da ANPT junto ao STF, apresentados na ordem cronológica em que chegaram à Corte e foram determinando a atuação dos atores e instituições envolvidas.

\section{A arena judicial trabalhista em disputa}

No Brasil, a construção jurisprudencial dos tribunais da Justiça do Trabalho tem tido um papel relevante na definição de direitos e, como algumas pesquisas demonstraram (SILVA, 2011; ARTUR, 2012; FREITAS, 2012), reflete "o encontro direto com as circunstâncias sociais e políticas da sociedade" (PESSANHA e NORONHA, 2013). Assim, conforme apontam os trabalhos liderados por Pessanha, enquanto na "década neoliberal" de 1990 ocorreu um uso da jurisprudência para inibir direitos dos trabalhadores, nos anos 2000 nota-se uma atuação do Tribunal Superior do Trabalho (TST) e de Tribunais Regionais do Trabalho em favor da recuperação e do desenvolvimento de direitos a partir de princípios de ordens normativas externas à legislação trabalhista estrita, presentes nos dispositivos da Constituição de 1988 e nas Convenções adotadas pela Organização Internacional do 
Trabalho (OIT) e outros organismos internacionais (PESSANHA, ALEMÃO e SOARES, 2009; PESSANHA e NORONHA, 2013).

Em relação à abertura da arena trabalhista, analisando o papel do TST na produção legislativa do trabalho no Brasil, Freitas (2012) mostrou que a presidência do TST atuou de forma pouco visível e com foco exclusivo na regulamentação da estrutura da Justiça do Trabalho nos processos da Assembleia Nacional Constituinte de 1987-1988. Com o tempo, essa atuação foi se modificando, passando a ser mais visível e inclusiva de outros temas da área do trabalho.

Para isso, segundo a autora, contribuíram como fatores internos à instituição tanto o poder de agenda de cada presidente do TST (escolhido em razáo de uma cultura jurídica de respeito à hierarquia e à sua antiguidade no Tribunal) como estruturais como o aumento do número de ministros pela norma constitucional que abriu a possibilidade de renovação dos ministros do Tribunal. Já os fatores conjunturais apontados expressaram-se na elevação do número de processos na Justiça do Trabalho e na disseminação de teses pela extinção da Justiça do Trabalho e nas propostas de reforma do Poder Judiciário - que levaram o Tribunal a se posicionar sobre o papel a ser desempenhado pela Justiça do Trabalho- e, por outro, na nova agenda trabalhista do governo Lula e no papel atuante da Associação Nacional dos Magistrados da Justiça do Trabalho (ANAMATRA) e do Ministério Público do Trabalho (MPT) na defesa dos chamados direitos humanos do trabalho.

Analisando o papel do MPT na produção de políticas públicas, Artur (2016) defende que sua atuação estratégica é fruto não apenas da ação dos procuradores do trabalho individualmente considerados, mas de sua atuação coordenada que, por sua vez, também é resultante da mobilização do direito realizada por atores sociais com o suporte de entidades como a OIT, dentro dos arranjos institucionais desenhados pela Constituição de 1988. Assim, o seu novo papel conferido pela Constituição Cidadã deve ser entendido dentro de um modelo de atuação que buscou permeabilidade a esse ambiente, ou de modo a ampliar as bases de um constitucionalismo social.

Apesar de pesquisas da área do trabalho apontarem para a reunião de esforços do MPT, de outros agentes estatais e da sociedade civil para o cumprimento dos direitos, tal como proposto por Vianna et al. (1999), as análises não podem prescindir das dificuldades organizacionais e institucionais para que isso se concretize (ARTUR, 2016). Desse modo, deve-se tratar do tema a partir das mudanças do Poder Judiciário dentro de contextos específicos (MACIEL e KOERNER, 2002).

Taylor (2007) apresenta o Poder Judiciário brasileiro como um ator capaz de 
impor decisóes e de incluir novos interesses no jogo político, modificando a forma com que as políticas públicas podem ser implementadas. Considerando isso, nossa análise sobre a relação entre o STF e a ANPT na defesa dos direitos sociais do trabalho trata de duas questóes mais amplas levantadas na literatura.

A primeira envolve o "longo poder constituinte do STF", sendo um dos mais importantes deles o de restringir as possibilidades de acesso ampliado à jurisdiçẫo constitucional conferida pela Constituição de $1988^{2}$, o que está relacionado aos constrangimentos institucionais para a construçáo da legitimidade dos atores para direcionarem as políticas públicas (SILVA, 2016; ARGUELHES e RIBEIRO, 2016).

Em relação aos terceiros legitimados a participarem das audiências públicas, enquanto as associações empresariais tendem a ser aceitas como amicus curiae sem maiores discussóes por parte da Corte, dada a imediata conexão entre livre iniciativa e interesse temático, as associações de juristas do trabalho nem sempre têm suas justificativas de defesa do interesse público aceitas, sob a alegação de que o objeto do controle não guardaria relação com os interesses específicos da categoria profissional representada (ver Quadro 3, na próxima seção, para as ações da ANPT negadas pela Corte).

Além de determinar quem são os atores legitimados para participar da definição das políticas, o STF também interpreta quais os temas podem ser objeto de análise por parte da Corte. Dessa forma, tem tratado os conflitos sobre questóes trabalhistas como problemas constitucionais que devem ser objeto de suas decisóes, aumentando, assim, seu poder institucional sobre essa arena, influenciando a agenda da política e as decisões dos outros Poderes (ver Quadro 1, para a as ações da ANPT aceitas pela Corte).

\footnotetext{
${ }^{2}$ Com a Constituição Federal de 1988, o país é caracterizado como de amplo acesso à Corte, conforme o art. 103: "Podem propor a ação direta de inconstitucionalidade e a ação declaratória de constitucionalidade: I - o Presidente da República; II - a Mesa do Senado Federal; III - a Mesa da Câmara dos Deputados; IV - a Mesa de Assembleia Legislativa ou da Câmara Legislativa do Distrito Federal; V - o Governador de Estado ou do Distrito Federal; VI - o Procurador-Geral da República; VII - o Conselho Federal da Ordem dos Advogados do Brasil; VIII - partido político com representação no Congresso Nacional; IX - confederação sindical ou entidade de classe de âmbito nacional”. Isso não impede, contudo que uma análise mais atenta desse acesso seja realizada.
} 
Quadro 1 - Principais açóes no STF das quais participa a ANPT na defesa do direito do trabalho como propositora ou como amicus curiae

\begin{tabular}{|c|c|}
\hline Açáo/autor & Principal fundamento \\
\hline $\begin{array}{l}\text { Ação Direta de } \\
\text { Inconstitucionalidade (ADI) } \\
\text { proposta pela Confederaçáo } \\
\text { Nacional dos Trabalhadores } \\
\text { na Indústria (CNTI), em } \\
2004 \text { - ADI } 3357\end{array}$ & $\begin{array}{l}\text { Inconstitucionalidade da Lei Estadual n. } 11.643 / 2001 \text { - Rio Grande } \\
\text { do Sul, que impóe restriçóes à utilização do amianto naquele estado. } \\
\text { Além da ADI 3357, outras açóes relativas foram examinadas pela } \\
\text { Corte: contra leis do estado de São Paulo (ADI 3.937), de 2007, e } \\
\text { do estado de Pernambuco (na ADI 3.356), de 2004. }\end{array}$ \\
\hline $\begin{array}{l}\text { ADI proposta pela ANPT e } \\
\text { pela ANAMATRA, em } 2008 \\
\text { - ADI } 4066\end{array}$ & $\begin{array}{l}\text { Inconstitucionalidade da Lei 9.055/1995, que permite a exploração, } \\
\text { industrialização e comercialização do amianto. }\end{array}$ \\
\hline $\begin{array}{l}\text { Arguição de } \\
\text { Descumprimento de Preceito } \\
\text { Fundamental (ADPF) } \\
\text { proposta por Confederação } \\
\text { Nacional dos Trabalhadores } \\
\text { na Indústria (CNTI), em } \\
2007 \text { - ADPF } 109\end{array}$ & $\begin{array}{l}\text { Inconstitucionalidade da Lei n. 13.113/2001 e o Decreto n. } \\
41.788 / 2002 \text {, do Município de São Paulo, proíbem a utilização na } \\
\text { construção civil de materiais construtivos e equipamentos } \\
\text { constituídos por amianto. }\end{array}$ \\
\hline $\begin{array}{l}\text { ADPF proposta por } \\
\text { Associação Nacional do } \\
\text { Transporte de Cargas e } \\
\text { Logística, em } 2011 \text { - ADPF } \\
234\end{array}$ & $\begin{array}{l}\text { Pleiteia a declaração de inconstitucionalidade da Lei n. } \\
12.684 / 2007 \text {, do Estado de São Paulo, que proíbe o uso, naquele } \\
\text { Estado, de produtos, materiais ou artefatos que contenham } \\
\text { quaisquer tipos de amianto ou asbesto. }\end{array}$ \\
\hline $\begin{array}{l}\text { ADI proposta pela } \\
\text { Confederação Nacional da } \\
\text { Indústria (CNI), em } 2007 \text { - } \\
\text { ADI } 3931\end{array}$ & $\begin{array}{l}\text { Inconstitucionalidade de dispositivos que estabelecem regras e o } \\
\text { método a ser utilizado para a caracterização de acidente do trabalho. }\end{array}$ \\
\hline $\begin{array}{l}\text { Arguição de } \\
\text { Descumprimento de Preceito } \\
\text { Fundamental proposta por } \\
\text { Associação Brasileira de } \\
\text { Agronegócio (ABAG), em } \\
2014 \text { - } \\
\text { ADPF } 324\end{array}$ & $\begin{array}{l}\text { Alega inconstitucionalidade de decisóes adotadas pela Justiça do } \\
\text { Trabalho para coibir a terceirização ilícita ou fraudulenta por } \\
\text { supostamente ferir a livre iniciativa. }\end{array}$ \\
\hline
\end{tabular}


ADI proposta pela

Confederação Nacional da

Agricultura e Pecuária do

Brasil (CNA), em 2014

ADI 5115
Inconstitucionalidade das Portarias do Ministério do Trabalho e Emprego que organizam o Cadastro de Empregadores que tenham mantido trabalhadores em condiçóes análogas a de escravo.

Fonte: Elaboração própria, utilizando-se de informações obtidas a partir do site do STF.

O trabalho de Koerner e Freitas (2013) mostra que, durante os trabalhos constituintes, os ministros do STF atuaram de modo incisivo para combater mudanças nas iniciativas de alteração das instituições de controle jurisdicional, preservando seus poderes concentrados, fortalecendo o insulamento do Poder Judiciário. Segundo os autores, no período pós-constituinte, "os juízes passariam a inocular em seus julgamentos as inovaçôes políticas e sociais trazidas pela nova Constituição" (KOERNER e FREITAS, 2013).

Essas elites jurídicas também atuaram ao longo dos debates sobre a Reforma do Judiciário no sentido da prevalência de uma agenda voltada para a centralização do poder em suas cúpulas e para o aumento da eficiência decisória em detrimento de uma agenda de acesso à justiça e de democratização da mesma (ALMEIDA, 2010).

Ainda, nos guiamos na literatura sobre judicialização na América Latina que tem mostrado que as cortes tomam um número cada vez maior de decisões com profundas implicaçôes para a natureza da política e das políticas públicas. Essa mesma literatura pergunta se esse papel tem melhorado a democracia. Nesse sentido, questiona se toda manifestação da judicialização aumenta direitos ou se devemos inquirir se o maior ativismo dos tribunais promove o poder de certos grupos e a defesa dos direitos de propriedade, os quais, uma vez distribuídos de forma muito desigual, pioram a equidade (SIEDER, SCHJOLDEN e ANGELL, 2005).

Em relação à segunda questão posta pela literatura, sobre o STF se tratar de um lócus de contestação democrática de políticas (TAYLOR, 2007), perguntamos em que medida seus poderes de controlar o acesso e o timing de decisóes não estão favorecendo determinados grupos e limitando as possibilidades democráticas de deliberação pública sobre os temas dos direitos sociais do trabalho. Dentro do objeto de estudo, especificadamente, como esses poderes estão prejudicando o desenvolvimento de uma atuação do Ministério Público do Trabalho voltada para a afirmação dos direitos constitucionais e das convenções internacionais, para a diminuição das desigualdades nas relações de trabalho e de aproximação com as demandas da sociedade civil. 
Quadro 2 - Argumentos da ANPT nas açôes referentes ao quadro anterior

\begin{tabular}{|c|c|}
\hline Argumentos da ANPT & AÇÃO \\
\hline $\begin{array}{l}\text { Ingerência de interesses econômicos das empresas na autonomia dos trabalhadores } \\
\text { Não há níveis seguros de uso do amianto } \\
\text { A União, com a Lei n. } 9.055 / 1995 \text {, editou uma norma específica ao excetuar o tipo } \\
\text { crisotila, violando o princípio constitucional da dignidade humana } \\
\text { A Lei n. 9.055/1995 deve ser reexaminada à luz da Convençáo } 162 \text { da OIT }\end{array}$ & ADI 3357 \\
\hline $\begin{array}{l}\text { Não há nível seguro de exposição ao amianto } \\
\text { Abolição do amianto como sistemática internacional } \\
\text { Direito humano ao meio ambiente sadio } \\
\text { Convenção } 162 \text { da OIT } \\
\text { Existência de outros materiais como alternativa tecnológica e econômica } \\
\text { Ofensa ao direito à saúde e ao meio ambiente expressos na Constituição Federal de } \\
1988 \\
\text { Incoerência da tolerância jurídica da exploração econômica do amianto frente ao } \\
\text { princípio da dignidade humana } \\
\text { Necessidade de releitura da legislação a partir dos pactos de direitos humanos e } \\
\text { convençóes da OIT }\end{array}$ & ADI 4066 \\
\hline $\begin{array}{l}\text { Papel na defesa dos direitos dos trabalhadores } \\
\text { ANPT admitida em outras açóes } \\
\text { Inadequação da ADPF para controle de legalidade } \\
\text { Organizaçáo global da resistência ao banimento do amianto pelas empresas } \\
\text { Direito humano ao meio ambiente sadio } \\
\text { Reitera os argumentos de associaçóes de saúde e de trabalhadores sobre a } \\
\text { nocividade do amianto } \\
\text { Prevalência da dignidade da pessoa humana, do valor social do trabalho, do meio } \\
\text { ambiente saudável como direito de todos em relaçáo a outros princípios da livre } \\
\text { iniciativa e, até mesmo, de possível repartição formal de competências. }\end{array}$ & ADPF 109 \\
\hline $\begin{array}{l}\text { ANPT admitida em outras açóes e seu papel na defesa dos direitos dos trabalhadores } \\
\text { Inadequação da ADPF } \\
\text { O Pleno manteve a eficácia da lei estadual de São Paulo no julgamento da } \\
\text { medida cautelar deferida pelo relator na ADI n. 3.937-7/SP. } \\
\text { Prevalência da dignidade da pessoa humana, do valor social do trabalho } \\
\text { do meio ambiente saudável como direito de todos em relação a outros princípios da } \\
\text { livre iniciativa e, até mesmo, de possível repartição formal de competências. }\end{array}$ & ADPF 234 \\
\hline Atuaçáo na defesa do meio ambiente do trabalho & ADI 3931 \\
\hline
\end{tabular}




\begin{tabular}{|l|l|}
\hline $\begin{array}{l}\text { Terceirização na da atividade-fim representa piora nas condiçóes sociais dos } \\
\text { trabalhadores } \\
\text { A livre iniciativa deve ser examinada em cotejo com o valor social do trabalho }\end{array}$ & ADPF 324 \\
\hline Matéria afeita à atuaçáo do MPT & ADI 5115 \\
\hline
\end{tabular}

Fonte: Elaboração própria, utilizando-se de informaçóes obtidas a partir do site do STF.

De fato, nas açôes objeto desse estudo, por longos anos não houve julgamentos definitivos no Plenário ${ }^{3}$ e o poder dos ministros individualmente considerados de promover suas decisóes monocráticas como parte do poder constituinte institucional da Corte é uma realidade na arena trabalhista. Isso é importante porque, segundo Arguelhes e Ribeiro (2016), coloca "o problema do grau de liberdade e de poder que os ministros dispõem", e, desse modo, de ausência de controles externos sobre suas vontades, que determinam o timing de suas decisões e, portanto, também influenciam nas políticas de forma individualizada.

\section{Meio ambiente do trabalho}

O tema da defesa do meio ambiente do trabalho entra na agenda do MPT com a criação da Coordenadoria Nacional de Defesa do Meio Ambiente do Trabalho (CODEMAT), em 2003, que teve como inspiração para a articulação estratégica o Fórum Pernambucano de Combate aos Efeitos dos Agrotóxicos na Saúde do Trabalhador, no Meio Ambiente e na Sociedade. Além dessa mudança organizacional, mudanças institucionais em relação ao Poder Judiciário também contribuíram para o desenvolvimento de ações do MPT nessa área. A edição da Súmula 736, pelo STF, em 2003, trouxe para a Justiça do Trabalho as questóes relativas ao meio ambiente do trabalho e, assim, para o MPT, as atribuiçóes para a investigação e ajuizamento dessas açóes coletivas. Anos mais tarde, em 2009, por meio da atuação da ANAMATRA junto ao STF, a Súmula Vinculante 22 determinou a competência da Justiça do Trabalho para processar e julgar as ações de

\footnotetext{
${ }^{3}$ Apenas em agosto de 2017, dispositivo da lei federal que autoriza a produçáo e a venda do amianto passou a ser considerado inconstitucional. A dificuldade de formação de maioria para essa decisão, o longo período para que a questão fosse julgada no pleno, as decisóes monocráticas dos ministros, a mobilização do direito e a discussão sobre o acesso dos atores para participarem dessas ações mostram a importância dos estudos que abordem as regras institucionais e seu uso pelos atores na determinação das políticas.
} 
indenização por danos morais e patrimoniais decorrentes de acidente de trabalho, propostas por empregado contra empregador. Essas mudanças institucionais de competência, além do desenvolvimento de uma jurisprudência do TST positiva, em determinadas matérias relacionadas ao meio ambiente do trabalho, têm estimulado a atuação coordenada dos procuradores do trabalho no tema (ARTUR, 2016).

Um foco da ação estratégica do MPT nessa área é o banimento do amianto, considerado um material cancerígeno e mobilizado internacionalmente como uma questão de direitos humanos.

Em 2003, o STF decidiu pela inconstitucionalidade de dispositivos de leis dos estados de São Paulo (ADI 2656) e de Mato Grosso do Sul (ADI 2396) que proibiam o uso de amianto ${ }^{4}$. Nos dois julgamentos, o Plenário reconheceu que as disposiçóes contestadas invadiram a competência legislativa da União sobre normas gerais relativas à produção e consumo, proteçáo do meio ambiente e controle da poluição e à proteção e defesa da saúde.

A partir de 2004, a Confederação Nacional dos Trabalhadores na Indústria (CNTI) propôs diferentes Açóes Diretas de Inconstitucionalidade contra leis estaduais (e municipais) que restringiram a exploração do amianto naqueles âmbitos. A ANPT pediu sua participação como amicus curiae nessas ações, tendo resultados variados (ver Quadro 3).

\footnotetext{
4 Ambas açốes foram promovidas em razão dos interesses dos estados produtores de amianto, especialmente Goiás.
} 
Quadro 3 - Trâmites das açóes e argumentos dos relatores para aceitar ou negar a atuação da ANPT

\begin{tabular}{|c|}
\hline \\
\hline $\begin{array}{l}\mathrm{Na} \text { ADI 3356, o relator não admitiu a ANPT porque a mesma pediu sua } \\
\text { entrada no processo quando já havia sido iniciado o julgamento. NA ADI } \\
\text { 3937, o relator não a admite argumentando que procurador Geral já } \\
\text { representaria o Ministério Público. }\end{array}$ \\
\hline $\begin{array}{l}\text { Ministro relator Ministro Carlos Ayres Britto, admite a ANPT, em 2008, } \\
\text { como amicus curiae dada a relevância da matéria e a representatividade da } \\
\text { ANPT. } \\
\text { O Pleno manteve a eficácia da lei estadual de Sáo Paulo no julgamento } \\
\text { da medida cautelar deferida pelo relator na ADI n. 3.937-7/SP, Ministro } \\
\text { Marco Aurélio, em } 2008 \text {. } \\
\text { Após o voto do Ministro Ayres Britto (Relator), julgando improcedente a } \\
\text { açáo } 3357 \text {, e o voto do Ministro Marco Aurélio julgando- a procedente, } \\
\text { o julgamento foi suspenso- Plenário, } 2012 \text {. } \\
\text { Após o voto do Ministro Edson Fachin, que julgava improcedente o } \\
\text { pedido formulado na ação, pediu vista dos autos o Ministro Dias Toffoli- } \\
\text { Plenário, } 2016 \text {. }\end{array}$ \\
\hline
\end{tabular}

Ação recebida pelo então relator: Ministro Carlos Ayres Britto por constituir tema de importância para a ordem social e a segurança jurídica.

ADI 3357 AÇÃO ADI 3356

ADI 3937

Indeferida a liminar pelo relator Ministro Lewandowsk.

O novo relator, ministro Edson Fachin, admite a ANPT, em 2008, como amicus curiae por sua representatividade tanto pelo âmbito nacional como em sua finalidade de defesa dos direitos dos trabalhadores, ADPF 109 especialmente naquilo que diz respeito ao seu ambiente de trabalho e sua segurança.

O relator vota pela improcedência da ação.

Relator Ministro Marco Aurélio admite a ANPT como amicus curiae, em 2011.

O relator defere parcialmente medida cautelar para determinar a

Suspensáo da eficácia das interdiçóes ao transporte praticado pelas empresas e determinado o sobrestamento do feito até o julgamento da ADI 3937 contra a referida lei, proposta pela CNTI.

Relatora ministra Carmem Lúcia admite a ANPT como amicus curiae, em 2015, pelo cumprimento de requisitos.

ADPF 234

ADI 4066

ADI 3931 
Relator ministro Luís Roberto Barroso admite a ANPT, em 2016, por poder contribuir com o debate e pela possibilidade de paridade de armas entre interesses distintos.

ADPF 324

$$
\begin{aligned}
& \text { Em 2015, o governo edita nova portaria e a relatora decide } \\
& \text { monocraticamente que os pontos questionados na peça inicial da ação } \\
& \text { foram sanados na Portaria superveniente. }
\end{aligned}
$$

Relator não admite ANPT e outras entidades, entendendo não configurar como interesses profissionais e por colocar o STF na situaçáo de ter que aceitá-las em todos os temas de repercussão geral.

\section{ADI 5115}

Fonte: Elaboração própria, a partir de site do STF.

Com isso, apontamos, aqui para mais um poder do relator, que é a possibilidade de incluir ou excluir os interessados em influenciar as decisóes do STF, de acordo com seus valores e visão sobre o papel da Corte. Uma vez aceitos, os argumentos do amicus curiae podem ser retomados pelos relatores em suas decisóes. Além disso, essa aceitação pode ser apresentada, pelos próprios atores, como uma fonte de legitimidade para novas atuações.

O relator de uma dessas açóes, ministro Marco Aurélio, deferiu o pedido de liminar, na ADI 3.937-SP, para suspender a Lei paulista 12.684/2007. A norma proibia o uso e a comercialização em São Paulo, com início em 1o de janeiro de 2008, de produtos que contivessem qualquer tipo de amianto em sua composição. Segundo o relator, “a lei trata de tema criando embaraços à comercialização de produto sobre o qual, de início, compete à União legislar, porquanto ao se proibir o uso e a comercialização no estado tem-se como alcançado o comércio interestadual”.

Nesta ação, relator indeferiu o pedido de amicus curiae da ANPT, alegando que o Procurador Geral já representa o Ministério Público. Assim, afastou a especificidade da atuação da instituição e inviabilizou a participação da associação. A associaçáo entrou com recurso contra a decisáo, defendendo "o papel pluralista e democrático consubstanciado na possibilidade de participação dos terceiros no processo" e esclarecendo que a atuação da entidade não se confunde com a do Ministério Público.

Nessas ações promovidas pela CNTI é possível distinguir dois grupos de interesses antagônicos. De um lado, os interesses econômicos de governadores dos 
estados produtores e de associaçóes empresariais que não querem deixar de explorar este material, além de representaçóes de trabalhadores que alegam o desemprego que seria decorrente do banimento como um argumento contrário à sua limitação. De outro, a visão da Associação Brasileira de Expostos ao Amianto (ABREA), da ANPT, da ANAMATRA, de centrais sindicais, dos estados que já procuraram limitar a comercialização e de outras entidades a favor dessa restrição.

$\mathrm{Na}$ Ação Direta de Inconstitucionalidade relativa à Lei Estadual n. 11.643/2001, do Rio Grande do Sul, que impõe restrições à utilização do amianto naquele estado, o relator à época, Ministro Carlos Ayres Britto, admite a ANPT como amicus curiae "ante a relevância da matéria e a representatividade da ANPT" (ESTADO DO RIO GRANDE DO SUL, 2001).

Em audiência, a ANPT alega que a CNTI tem uma comissão criada para defender os interesses econômicos custeados pelo Instituto Brasileiro de Crisotila, os quais estão em oposição à Associação Brasileira dos Expostos ao Amianto (ABREA). Assim, isso poderia ser caracterizado como um ato de ingerência na autonomia dos trabalhadores.

Reforça os argumentos técnicos de que não há níveis seguros para o uso do amianto e que, ainda que a corte tenha decidido anteriormente sobre a constitucionalidade da Lei Federal n. 9.055/1995, a qual proíbe a exploração, utilização e comercialização de todos os tipos de amianto, exceto o do tipo crisotila, essa lei deve ser reexaminada à luz da Convenção 162 da OIT, ratificada pelo Brasil, que trata da adoção de políticas de substituição do amianto para melhor adequação aos princípios constitucionais (BRASIL, 1995).

Em relação ao confronto em relação ao princípio federativo, a ANPT defende que a União, no uso de sua competência para editar uma norma geral, editou uma norma específica contrária ao direito constitucional ao meio ambiente saudável e à Convenção Internacional 162 da OIT. Além disso, a partir do histórico do projeto que originou a lei, o qual determinava a substituiçáa progressiva dos produtos que continham o amianto, e da atuação legislativa de outros estados que restringiram o uso do amianto, exorta à Suprema Corte reavaliar a constitucionalidade da lei federal à luz desses parâmetros, propondo que a interpretação possível é que a lei permite, mas não determina o uso do amianto crisotila.

Como atuação estratégica conexa a essa, em 2008, a ANPT e a ANAMATRA propõem uma Ação Direta de Inconstitucionalidade da própria Lei Federal n. 9.055/1995, que permite a exploração, industrialização e comercialização 
do amianto. Essa ação é recebida pelo então relator, Ministro Carlos Ayres Britto por constituir "tema de importância para a ordem social e a segurança jurídica" (BRASIL, 1995).

Defendem as entidades o banimento do amianto como uma sistemática internacional baseada no direito humano ao meio ambiente sadio, conforme a Convenção 162 da OIT, que aponta para a necessidade de adoção de alternativas tecnológicas e também enfatizam a "incoerência da tolerância jurídica da exploração econômica do amianto frente ao princípio da dignidade humana expresso na Constituição de 1988 ” e em face dos direitos relativos à saúde e ao meio ambiente presentes na Carta Cidadã.

Em 2008, "há mudança de entendimento da Corte", quando o Pleno do STF manteve a eficácia da lei estadual de São Paulo no julgamento da medida cautelar deferida pelo relator na $\mathrm{ADI}$ n. 3.937-7/SP5. Os fundamentos dessa decisão foram à Convenção OIT n. 162/86, na condição de "norma protetora de direitos fundamentais, em especial o direito à saúde e o direito ao meio-ambiente equilibrado", à qual todos os entes da federação devem adequar-se e a inviabilidade de diferenciar as normas gerais das normas específicas no tocante à hipótese do amianto, sob pena de suprimir todo e qualquer espaço legislativo dos Estados, "retirando-lhe a liberdade de atender, dentro de limites razoáveis, os interesses da comunidade".

$\mathrm{Na}$ ADPF 234, de 2011, que pleiteia a declaração de inconstitucionalidade da Lei n. 12.684/2007, do Estado de São Paulo, que proíbe o uso, naquele Estado, de produtos, materiais ou artefatos que contenham quaisquer tipos de amianto ou asbesto, a ANPT destaca que foi admitida em outras açóes, cita a mudança no entendimento da Corte na liminar da ADI 3.937-SP e o uso estratégico da ADPF para reformar este pronunciamento (ESTADO DE SÃO PAULO, 2007).

Dentro desse novo contexto institucional de mudança de entendimento da Corte, em seu pleno, o relator Marco Aurélio, ao contrário de outras açóes, admite a ANPT afirmando que "cumpre ouvir a requerente, ante o entrelaçamento da matéria versada na ADPF com a representação que lhe é própria”. Em 2011, nos termos do voto do relator e vencidos os votos dos ministros Ayres Britto, Celso de Mello e Ministro Cezar Peluso, é deferida parcialmente medida cautelar, ou seja, permitindo o transporte do amianto naquele Estado, e determinado o sobrestamento do feito até o julgamento da ADI 3.937-SP.

${ }^{5}$ STF - Pleno. ADI n. 3.937-7/SP (MC). Rel. Min. Marco Aurélio. DJ de 09.10.2008. 
Em 2016, o ministro Fachin admitiu a ANPT como amicus curiae, na ADPF 109 proposta pela CNTI, em 2007, contra a Lei n. 13.113/2001, do município de São Paulo, considerando sua representatividade em âmbito nacional e sua finalidade de defesa dos direitos dos trabalhadores, especialmente naquilo que diz respeito ao seu ambiente de trabalho e sua segurança (PREFEITURA DA CIDADE DE SÃO PAULO, 2001).

No pedido, a ANPT além de seu papel de defesa dos direitos dos trabalhadores, alega a sua admissão em outras ações. Ainda, aponta a mudança do entendimento da Corte no julgamento da liminar concedida pelo ministro Marco Aurélio, acima relatada, e afirma a inadequação do uso da ADPF como controle da legalidade.

No plano fático, avalia que há uma organização global de resistência ao banimento do amianto pelas empresas presentes em países mais periféricos. Traz os argumentos sobre a nocividade do amianto trazidos pelas associaçóes de saúde e de trabalhadores presentes na audiência pública.

Defende a prevalência da dignidade da pessoa humana, do valor social do trabalho, do meio ambiente saudável, como direito de todos em relação a outros princípios da livre iniciativa e, até mesmo, de possível repartição formal de competências. Assim, a competência da União, para legislar sobre produção e consumo, deve ser interpretada como limitada à edição de normas gerais, reservandose aos Estados e Municípios a competência para legislar complementarmente, adequando a legislação federal de princípios à sua realidade local, às suas especificidades, sempre em prol de um sentido mais protetivo à saúde e ao meio ambiente humano.

Afirmando o direito humano ao meio ambiente saudável, considera que cabe ao Poder Judiciário influenciar no processo legislativo para que o Estado não produza leis prejudiciais. Por fim, pede que as normas da OIT sobre o tema sejam interpretadas em conformidade o Pacto Internacional sobre Direitos Civis e Políticos (1966), o Protocolo de San Salvador (1988), o Pacto Internacional sobre Direitos Econômicos, Sociais e Culturais (1966), e de acordo com as Diretrizes e Resoluçôes da Organização Mundial da Saúde.

Em 2012, foi realizada uma audiência pública sobre o tema. No mesmo ano, após o voto do Ministro Ayres Britto (Relator), julgando improcedente uma ação e o voto do Ministro Marco Aurélio, julgando-a procedente, o julgamento foi suspenso. Em 2016, o Plenário retoma o julgamento das quatro ações ajuizadas pela CNTI 
impugnando leis de três estados (PE, RS e SP) e do Município de São Paulo, que proíbem a produção, comércio e uso de produtos com amianto nos respectivos territórios ${ }^{6}$. No entanto, após o voto do Ministro Edson Fachin, que julgou improcedente o pedido formulado nas açôes, o Ministro Dias Toffoli pediu vista dos autos.

Enquanto os votos dos ministros Aires Brito e Fachin buscam interpretar as leis restritivas do amianto como constitucionais em face dos princípios da Constituição e das normas internacionais - inclusive o ministro Fachin afirma como legítimas as leis que priorizam o direito ao meio ambiente sadio frente à livre iniciativa- o ministro Marco Aurélio explicita que faz a leitura desses dispositivos para afastar a prioridade desse direito ao meio ambiente sadio frente a um cenário anunciado de problemas econômicos, técnicos e de resolução de outros conflitos que poderiam advir do banimento do amianto, justificando a limitação da atuação do Poder Judiciário em favor de uma atuação legislativa ${ }^{7}$.

Outro foco de atuação estratégica da ANPT dá-se na questão do Nexo Técnico Epidemiológico Previdenciário (NTEP). Um passo importante na defesa da saúde do trabalhador foi a adoção pelo governo de Luís Inácio Lula da Silva do NTEP, que estabelece a relação estatístico-epidemiológica entre o CID e o segmento de atividade econômica - Classificação Nacional de Atividades Econômica (CNAE) com base na série histórica dos benefícios concedidos pelo INSS. Trata-se, portanto, de uma estratégia de adoção de um conceito amplo de defesa da saúde coletiva que visa superar a abordagem médica individual, tal como preconizado na Constituiçáo Federal de 1988. No entanto, pesquisas têm apontado que em setores com trabalhadores tipicamente precarizados, como os call centers, as empresas estariam utilizando-se de uma tática de ocultação dos adoecimentos, com a queda na emissão

\footnotetext{
${ }^{6}$ Além da ADI 3357, do Rio Grande do Sul, foram examinadas pela Corte a referente ao estado de Pernambuco (ADI 3.356) e do estado São Paulo (ADI 3.937), além da ADPF 109 contra o município de São Paulo.

7 A atuação legislativa, contudo, tem-se dado no sentido de afirmar o uso do amianto. Nesse sentido, o projeto 176/2011 classifica o resíduo proveniente da atividade de mineração e industrialização do amianto ou asbesto e dos produtos que o contenham, inclusive como contaminante, como sendo Classe I ou "Resíduo industrial perigoso" para fins de sua destinação final. Em sua agenda política, a ANPT manifesta-se contrária à aprovação do projeto, pois pressupõe a utilização, comercialização e exposição de trabalhadores ao amianto.
} 
da Comunicação de Acidente do Trabalho (CAT), após o início do nexo epidemiológico (FILGUEIRAS e DUTRA, 2014).

Atualmente, a Confederação Nacional da Indústria propôs a Ação Direta de Inconstitucionalidade 3931, de 2007, que pleiteia a inconstitucionalidade de artigos da legislação que regula o NTEP. Ainda não há decisóes sobre o pedido.

A ministra relatora não admitiu a ANAMATRA na condição de amicus curiae, alegando ausência de pertinência temática, uma vez que a legitimidade afirmada pela associação na defesa da Constituição seria genérica, na sua visão.

A leitura do art. $2^{\circ}$ do Estatuto da Anamatra conduz à conclusão de não estar incluída entre as suas a finalidade de defender a constitucionalidade de normas que disciplinem as relaçóes de emprego ou a concessão de benefício decorrente de uma relação de emprego. [...] A pertinência temática também é requisito para a admissão de amicus curiae e a Requerente não o preenche. Reduzir a pertinência temática ao que disposto no estatuto das entidades sem considerar a sua natureza jurídica colocaria o Supremo Tribunal Federal na condição submissa de ter que admitir sempre qualquer entidade em qualquer ação de controle abstrato de normas como amicus curiae, bastando que esteja incluído em seu estatuto a finalidade de defender a Constituição da República. 6. Pelo exposto, indefiro o pedido de intervenção na ação na condição de amicus curiae (art. $7^{\circ}, \mathbb{}, 2^{\circ}$, da Lei n. 9.868/1999) (Min. Carmem Lúcia, 21 de maio de 2015, grifos nossos).

Por outro lado, no mesmo ano, a mesma relatora, mudando de posicionamento, aceitou os argumentos da ANPT para aceitá-la como amicus curiae, repetindo os argumentos da associação para determinar que haviam sido comprovados os requisitos de legitimidade e pertinência temática. Esses argumentos afirmaram que o aprimoramento da efetividade da tutela dos trabalhadores é gravado no seu estatuto e que a atuação dos membros do MPT no âmbito do meio ambiente do trabalho a credencia para contribuir.

Essa divergência de entendimentos sobre a possibilidade de atuação das associaçôes de juristas do trabalho, na defesa de direitos sociais, tem sido constante, conforme também veremos no tema da terceirização. Entendemos que a decisão do relator sobre quais entidades que devem ou nâo participar como amicus curiae reforça o poder de cada ministro de legitimar quais atores podem trazer seus argumentos na definição da política pública. Tais argumentos, assim, podem ajudar a compor suas 
decisões monocráticas, quando são retomados pelos ministros ou pelas diferentes partes para direcionar entendimentos futuros. Foi o que aconteceu com a ANPT, que passou a utilizar os novos entendimentos da Corte e de argumentos presentes nas açôes nas quais foi aceita, para reforçar seus pedidos e sua legitimidade de atuação.

\section{Terceirização}

O tema da terceirização tem sido objeto do STF em âmbito de repercussão geral. Em 2016, o relator admitiu o recurso que ataca a normatização da terceirização realizada pelo Tribunal Superior do Trabalho $(\text { TST })^{8}$. A tese aceita é de que a Súmula 331 do TST $^{9}$ fere o princípio da legalidade e da livre iniciativa. Este argumento de que dispositivos são contrários à livre iniciativa tem sido recorrente nas açóes citadas, garantindo livre acesso ao STF pelas entidades empresariais de âmbito nacional.

\footnotetext{
${ }^{8}$ Recurso Extraordinário com Agravo 713.211.

9 O Enunciado 331 foi aprovado pela Resolução Administrativa n. 23, de 17 de dezembro de 1993.
} Seu inciso IV foi alterado por meio da Resolução administrativa n. 96, de 11 de setembro de 2000, conferindo responsabilidade subsidiária à Administração Pública. Em 2011, diante do julgamento da Ação Direta de Constitucionalidade 16, este inciso sofreu nova redação e dois novos incisos foram acrescentados. Esta mudança visou a determinar que tal responsabilidade não resulta de mero inadimplemento das obrigaçóes trabalhistas pela empresa contratada, mas principalmente da conduta culposa da Administração Pública em não fiscalizar o cumprimento das obrigações contratuais e legais da prestadora dos serviços. A atual redação da Súmula 331 é a seguinte:

"Contrato de prestação de serviços- legalidade- revisão do Enunciado n. 256.

I- A contratação de trabalhadores por empresa interposta é ilegal, formando-se o vínculo diretamente com o tomador de serviços, salvo no caso de trabalho temporário (Lei n. 6.019, de 3.1.74);

II- A contratação irregular de trabalhador, através de empresa interposta, não gera vínculo de emprego com os órgãos da Administração Pública Direta, Indireta ou Fundacional (art. 37, II, da Constituição da República);

III- Não forma vínculo de emprego com o tomador a contratação de serviços de vigilância (Lei n. 7013, de 20.06.83), de conservação e limpeza, bem como a de serviços especializados ligados à atividade-meio do tomador, desde que inexistente a pessoalidade e a subordinação direta.

IV - O inadimplemento das obrigaçóes trabalhistas, por parte do empregador, implica a responsabilidade subsidiária do tomador de serviços quanto àquelas obrigaçóes, desde que haja participado da relaçáo processual e conste também do título executivo judicial.

$\mathrm{V}$ - Os entes integrantes da administração pública direta e indireta respondem subsidiariamente, nas mesmas condiçóes do item IV, caso evidenciada a sua conduta culposa no cumprimento das obrigaçóes da Lei n. 8.666/93, especialmente na fiscalização do cumprimento das obrigaçóes contratuais e legais da prestadora de serviço como empregadora. A aludida responsabilidade não decorre de mero inadimplemento das obrigações trabalhistas assumidas pela empresa regularmente contratada. 
Nesse recurso, a empresa Celulose Nipo Brasileira S/A - CENIBRA questionou a decisão proferida na ação civil pública movida pelo Ministério Público do Trabalho e pelo Sindicato dos Trabalhadores nas Indústrias Extrativas de Guanhães e Região, que a condenou a se abster de contratar mão de obra terceirizada para sua atividade-fim. Com a repercussão geral, o Supremo Tribunal Federal ensejou o debate do tema da terceirização à luz da livre iniciativa e do princípio da legalidade. Ainda, abriu a discussão sobre se é ou não permitido à Justiça do Trabalho determinar a cessação da conduta de terceirização, que sujeita os trabalhadores a regimes normativos caracterizados pela reduçáo de custos pela diminuição de direitos, e condenar a empresa a indenizar pelos danos coletivos causados.

Houve uma forte mobilização, gerando diversos pedidos para participar do processo como amicus curae: 24 organizaçôes empresariais em defesa da ampla terceirização e 14 interessados em favor da decisão da Justiça do Trabalho, incluindo entidades profissionais, centrais sindicais, dois núcleos universitários de pesquisa ou extensão e duas associações de magistrados e procuradores ${ }^{10}$. A ANAMATRA, a ANPT, o SINAIT (Sindicato Nacional dos Auditores Fiscais do Trabalho) e os núcleos universitários não foram aceitos pelo relator como amicus curiae. Assim se pronunciou o relator negando o ingresso como amicus curiae das associações ANPT e da ANAMATRA e do SINAIT:

Relativamente às associaçóes de classe ANPT, SINAIT e ANAMATRA, em especial, resta evidente que o tema versado nos autos não figura dentre os interesses institucionais das carreiras por elas representadas. Dessa forma, não apenas o indeferimento da intervenção se impóe, como também se trata de medida salutar em vista da necessária imparcialidade com que os órgãos integrados pelos seus associados devem atuar na matéria. Além disso, entendimento contrário exigiria a manifestação dessas mesmas associaçóes em todo e qualquer processo abordando tema trabalhista que seja analisado por esta Corte. Mais ainda, por esse raciocínio, associações de classe da Magistratura e do Ministério Público deveriam participar do

\footnotetext{
${ }^{10}$ Dados do Relatório parcial da pesquisa sobre "Reconfiguraçóes institucionais e trabalho decente: os debates sobre terceirização laboral no Brasil contemporâneo", sistematizados pelos graduandos do CIRT-UFRJ Antônio Leonardo Silva Carneiro e Márcio Barcelos Tarouco Corrêa (PIBIC/CNPq UFRJ) a partir de levantamento realizado nos autos eletrônicos e andamento dos processos STF-RE 958252 e agravo em RE 713.211. Agradecemos à orientadora do trabalho, profa. Profa. Dra. Sayonara Grillo Coutinho Leonardo da Silva, por disponibilizá-los.
} 
julgamento de todos os Recursos Extraordinários e açóes de controle concentrado de constitucionalidade no Supremo Tribunal Federal. O absurdo da proposição demonstra o acerto da decisão que não acolheu o pleito das referidas entidades de classe como amici curiae (Min. Fux, Brasília, 03 de novembro de 2016, grifos nossos).

A decisão do relator, acima apresentada, reforça a interpretação para restringir a participação dessas associações como amicus curiae. Consequentemente, também dificulta que as mesmas promovam uma atuação de defesa dos direitos sociais do trabalho. Silva (2016), tratando do processo interpretativo pelo qual a Corte tem estabelecido que a expressão entidade de classe refere-se à associaçáo de pessoas pertencentes a uma mesma categoria, ressalta o caráter corporativo conferido à ideia de classe, segundo uma tradição jurídica pré-constitucional do direito do trabalho. Concordamos com autor no sentido de que decisão sobre o acesso ao STF é política e comporta outras interpretaçóes jurídicas alternativas.

De um modo distinto, admitindo a ANPT e das centrais sindicais como amicus curiae na Arguição de Descumprimento de Preceito Fundamental (ADPF) 324, dada sua "indiscutível representatividade de tais entidades na defesa dos interesses dos trabalhadores em geral e/ou dos respectivos sindicatos", assim se pronunciou outro relator sobre as diretrizes de admissão, as quais revelam uma concepção ampliativa da possibilidade de atuação dessas entidades:

O debate e possibilitar a coleta de subsídios e de informaçóes relevantes para a decisão do Supremo Tribunal Federal deve se pautar, por isso, i) pela representatividade dos requerentes, ii) pela potencial relevância da sua participação, tendo em vista a sua capacidade de tratar do assunto de forma ampla e sob os mais variados aspectos, bem como iii) pelo respeito à paridade de armas, ante a importância de instaurar o debate entre entidades com entendimentos distintos acerca de como o caso deve ser decidido. Deve-se, por outro lado, iv) evitar que o ingresso excessivo de intervenientes no processo comprometa seu bom andamento (Min. Roberto Barroso, Brasília, 03 de novembro de 2016, grifos nossos).

$\mathrm{Na}$ ADPF 324, a ANPT participa como amicus curiae em ação proposta pela Associação Brasileira de Agronegócio (ABAG), dirigida ao reconhecimento, com eficácia erga omnes e efeito vinculante, de uma suposta inconstitucionalidade de decisões adotadas pela Justiça do Trabalho para coibir a terceirização ilícita ou fraudulenta. 
Para tanto, a ANPT utiliza-se de informações do DIEESE (Secretaria Nacional de Relaçóes de Trabalho e Departamento Intersindical de Estatística e Estudos Socioeconômicos, 2014) que indicam que os trabalhadores terceirizados ganham menos, trabalham mais e estão mais sujeitos a acidentes de trabalho. Além disso, confrontam as práticas de terceirização que trazem trabalho em condições análogas a de escravo em sua cadeia com a agenda do Trabalho Decente, promovida pela OIT em conjunto com atores sociais e instituições no país. Afirmam que os trabalhadores terceirizados têm seus contratos sucessivamente extintos, sem adquirir o direito às férias anuais remuneradas. Defendem que a alta rotatividade prejudica a arrecadação do Fundo de Garantia do Tempo de Serviço, comprometendo a realização de políticas públicas. Do mesmo modo, argumentam que o direito à organização coletiva é seriamente afetado com a fragmentação das categorias em diferentes segmentos, com os trabalhadores terceirizados sendo distanciados dos processos de negociação. Além disso, contrapóem a discriminação injusta praticada nos pagamentos nas terceirizações ao instituto da equiparação salarial e à proibição de conduta discriminatória no âmbito das relações empregatícias.

Esses argumentos também estão presentes na discussão do tema na arena legislativa. A Análise da tramitação do PLC 30/2015, antigo projeto de lei 4330/2004, mostra um longo processo de idas e vindas, marcado por audiências públicas, que culminou na tensão do pedido de urgência de votação do então presidente da Câmara dos Deputados. Nesse clima, o STF também aparece como uma instituição determinante em dois momentos. No primeiro, o presidente da Câmara, diz que a Corte pediu que o Poder Legislativo tratasse sobre o tema. No segundo, um parlamentar alega que os votos da Corte estavam tendendo a declarar a inconstitucionalidade da súmula do TST e que por isso deveriam votar a favor do projeto.

Após a aprovação do projeto na Câmara e seu encaminhamento para discussão no Senado, o ambiente político do país a partir de 2016 tornou o cenário favorável à reforma trabalhista e à adoção de proposições que buscam institucionalizar a terceirização de forma mais ampla, desconsiderando as questóes que foram debatidas ao longo de décadas. Assim, por meio de uma manobra legislativa, voltou à tramitação na Câmara dos Deputados o antigo PL n. 4.302/1998, de iniciativa do governo Fernando Henrique Cardoso, e já aprovado em primeiro turno nas duas casas do Congresso Nacional, que restitui ao empresariado amplo poder sobre a força 
de trabalho. Desse modo, foi aprovada a Lei n. 13.429, de 31 de março de 2017 (BRASIL, 2017).

Com a edição da nova lei, recentemente, a Associação Brasileira do Agronegócio e Associação Brasileira do Telesserviço manifestaram-se na ADPF 324, bem como a ANPT. Desse modo, esse tema merece continuar sendo estudado para análise de desdobramentos.

\section{Trabalho escravo}

Antes de tratarmos das ações das quais a ANPT participa, é importante dizer que atuação do Ministério Público do Trabalho no combate ao trabalho escravo dá-se não apenas por meio de procedimentos institucionais judiciais e extrajudiciais, mas também na formulação e implementação de políticas públicas, incluindo na mobilização no Congresso Nacional pela manutenção da legislação que traz o conceito de trabalho escravo como aquele realizado em condiçóes degradantes e em desrespeito à dignidade humana ${ }^{11}$, que tem norteado suas ações.

Um instrumento importante da política de combate ao trabalho escravo é o Cadastro dos Empregadores, feito a partir de processo administrativo que concluiu pela ocorrência de mão-de-obra sujeita ao trabalho escravo. Em 2014, duas ações diretas de inconstitucionalidade foram apresentadas contra as Portarias do Ministério do Trabalho e Emprego que organizam esse cadastro: a Ação Direta de Inconstitucionalidade n. 5209/DF, na qual o ministro relator proferiu liminar contra a publicação do cadastro, e a ação direta de inconstitucionalidade n. 5115, ajuizada pela Confederação Nacional de Agricultura e Pecuária do Brasil (CNA).

Enquanto essas associaçóes empresariais alegam que as Portarias contrariam princípios do devido processo legal, o Ministro do Trabalho e Emprego e as associações que fizeram o pedido de amicus curiae para defender o Cadastro, dentre elas a ANPT, afirmam que o mesmo é destinado a efetivar uma política estatal destinada a proteger a dignidade humana protegida em âmbito constitucional e nos compromissos internacionais assumidos pelo país no combate ao trabalho escravo.

No período das açóes, o Ministério do Trabalho e Emprego edita nova portaria e a ministra relatora da $\mathrm{ADI}$ n. 5115, Cármen Lúcia, em decisão

\footnotetext{
11 Em sentido contrário, o Projeto de Lei do Senado n. 432, de 2013 restringe o conceito de trabalho escravo àquele sob ameaça de punição, com uso de coação ou com restrição da liberdade pessoal, além de retenção no local de trabalho, vigilância ostensiva, apropriação de documentos do trabalhador e restrição da locomoção em razão de dívida contraída com o empregador ou representante.
} 
monocrática proferida em 2015, sustentou que a ausência de dispositivos para o exercício do direito à ampla defesa administrativa foi sanada pela nova Portaria n. 4/2016 (BRASIL, 2016).

Apesar de esse ser um tema em que a política pública foi modificada em diálogo com o STF, especialmente com a ministra relatora, no sentido de sua melhor aceitação jurídica, entendemos que a ausência de uma firme decisão do Pleno, no sentido de defender essa política estatal, acaba por deixar ambiguidades institucionais que são exploradas por atores que perderam momentaneamente com a decisão individual da ministra.

Aproveitando essas ambiguidades, o Ministério do Trabalho e Emprego do atual governo Michel Temer não publicou o Cadastro, o que levou a discussão novamente à Justiça do Trabalho.

\section{Considerações finais}

As associações de juristas do trabalho, especialmente a ANPT com objeto deste estudo, devem justificar quando pretendem defender algum interesse público e tais justificativas nem sempre são aceitas sob a alegação de que o objeto do controle não guardaria relação com os interesses específicos da categoria profissional representada.

Com isso, as decisões dos ministros do STF podem limitar as vozes institucionais que se aproximam das demandas da sociedade civil, na defesa dos direitos sociais do trabalho e reforçar o poder da Corte e dos ministros individualmente considerados de direcionar as políticas públicas sobre o tema. Isso contribui para ampliar o distanciamento da Corte em relação à realidade das desigualdades produzidas pela regulação do trabalho.

Por outro lado, apesar dos constrangimentos institucionais, as ações promovidas pela ANPT, aqui abordadas, indicam que a associação buscou legitimar os âmbitos de sua atuação estratégica nos temas da terceirização, do meio ambiente do trabalho e do combate ao trabalho escravo, por meio de um diálogo com entidades de defesa dos direitos dos trabalhadores e com o STF, principalmente aproveitando a oportunidade aberta com o recebimento de suas ações por determinados ministros relatores. Com isso, ajudou a introduzir argumentos a favor de uma leitura da legislação a partir de princípios constitucionais e de normas internacionais de direitos humanos, voltados para a justiça social. 
A dinâmica institucional da Corte influencia na definição das políticas. Nos casos estudados, o timing das decisóes do STF, as cautelares deferidas a favor de fortes interesses econômicos e a não aceitação de pedidos de amicus curiae em defesa dos direitos do trabalho colaboram com o descumprimento de tais direitos e com a deslegitimação das instituições trabalhistas.

Karen Artur é Doutora em Ciência Política, pela Universidade Federal de São Carlos (UFSCar). Bolsista CAPES de Pós-Doutorado no Programa de Pós-Graduação em Ciência Política da UFSCar. Email: karenartur2014@gmail.com.

Ligia Barros de Freitas é Doutora em Ciência Política, pela UFSCar. E Professora do curso de Direito da Universidade Estadual de Minas Gerais(UEMG).E-mail: ligiadefreitas@ig.com.br.

\section{Referências}

ALMEIDA, Frederico Normanha Ribeiro de. A nobreza togada: as elites jurídicas e a política da justiça no Brasil. 2010. 329 f. Tese de Doutorado (Doutorado em Ciência Política) - Programa de Pós-Graduação em Ciência Política. Universidade de São Paulo, 2010.

ARGUELHES, Diego Werneck; RIBEIRO, Leandro Molhano. Criatura e/ou Criador: transformaçóes do Supremo Tribunal Federal sob a Constituição de 1988. Revista Direito GV, v. 12, n. 2, p. 405440, 2016.

ARTUR, Karen. O novo poder normatizador do TST: dissídios individuais e atores coletivos. São Paulo: LTr, 2012.

ARTUR, Karen. Ministério Público do Trabalho: construção institucional e formação da agenda. Mediaçóes - Revista de Ciências Sociais, v. 21, n. 1, p. 167-198, 2016.

BRASIL. Lei n. 9.055, de $1^{\circ}$ de junho de 1995. Disciplina a extração, industrialização, utilização, comercialização e transporte do asbesto/amianto e dos produtos que o contenham, bem como das fibras naturais e artificiais, de qualquer origem, utilizadas para o mesmo fim e dá outras providências. D.O.U, 02/06/1995, p. 23371. Disponível em: <http://www.planalto.gov.br/ccivil_03/leis/L9055.htm>. Acesso em 20 nov. 2017.

BRASIL. Lei n. 13.429/2017, de 31 de março de 2017. Altera dispositivos da Lei n. 6.019, de 3 de janeiro de 1974, que dispóe sobre o trabalho temporário nas empresas urbanas e dá outras providências; e dispóe sobre as relaçóes de trabalho na empresa de prestação de serviços a terceiros. 
DOU, 31/03/2017, p. 1. Disponível em: <http://www.planalto.gov.br/ccivil_03/_ato20152018/2017/lei/L13429.htm>. Acesso em 20 nov. 2017.

BRASIL. Portaria Interministerial MTPS/MMIRDH n. 4, de 11 de maio de 2016. Dispóe sobre as regras relativas ao Cadastro de Empregadores que tenham submetido trabalhadores a condiçóes análogas à de escravo. DOU, 13 maio de 2016, p. 178. Disponível em: $<$ http://pesquisa.in.gov.br/imprensa/jsp/visualiza/index.jsp?jornal=1\&pagina $=178 \&$ data $=13 / 05 / 201$ 6>. Acesso em 20 nov. 2017.

ESTADO DE SÃO PAULO. Lei n. 12.684, de 26/07/2007. Proíbe o uso, no Estado de São Paulo de produtos, materiais ou artefatos que contenham quaisquer tipos de amianto ou asbesto ou outros minerais que, acidentalmente, tenham fibras de amianto na sua composição. DOE, 27/07/2007, p.4. Disponível em: <https:/www.al.sp.gov.br/norma/73261>. Acesso em 20 nov. 2017.

ESTADO DO RIO GRANDE DO SUL. Lei n. 11.643, de 21 jun. de 2001. Dispóe sobre a proibição de produção e comercialização de produtos à base de amianto no Estado do Rio Grande do Sul e dá outras providências. DOE n. 118, de 22 de junho de 2001. Disponível em: <http://www.al.rs.gov.br/legis/M010/M0100099.ASP?Hid_Tipo=TEXTO\&Hid_TodasNormas=18 69\&hTexto=\&Hid_IDNorma=1869>. Acesso em 20 nov. 2017.

FILGUEIRAS, V. Araújo; DUTRA, Renata Queiroz. Adoecimento no teleatendimento e regulação privada: a invisibilização como estratégia. Centro de Estudos Sindicais e Economia do Trabalho (CESIT). 2014. Disponível em: <http://indicadoresderegulacaodoemprego.blogspot.com.br/>. Acesso em: 10 jun. 2014.

FREITAS, Lígia Barros de. A consolidação institucional do Tribunal Superior do Trabalho na longa constituinte. 2012. 375 f. Tese de Doutorado (Doutorado em Ciência Política). Programa de PósGraduação em Ciência Política. Universidade Federal de São Carlos, 2012.

KOERNER, Andrei. O debate sobre a reforma judiciária. Novos Estudos CEBRAP, v. 2, n. 54, p. 11 26, 1999.

KOERNER, Andrei. Por uma História política do Pensamento Constitucional Republicano Brasileiro (1920-1888). In: Seelaender, Airton (Org.) Direito e História - Conceitos Fundamentais. São Pauo: Malheiros, 2012.

KOERNER, Andrei; FREITAS, Lígia Barros de O Supremo na constituinte e a constituinte no Supremo. Lua Nova, São Paulo, n. 88, p. 141-184, 2013.

MACIEL, Débora Alves; KOERNER, Andrei. Sentidos da judicialização da política: duas análises. Lua Nova, São Paulo, n. 57, p. 113-134. 2002.

PESSANHA, Elina Gonçalves da Fonte; ALEMÃO, Ivan e SOARES, José Luiz. TST, dissídios coletivos, demissão massiva: novos desafios para a Justiça do Trabalho. In: MELO FILHO, Hugo Cavalcanti; SOUTO MAIOR, Jorge Luiz; FAVA, Marcos Neves Fava (Org.). O Mundo do Trabalho: leituras críticas da jurisprudência do TST em defesa do direito do trabalho. São Paulo: LTr, 2009, p. 77-94.

PESSANHA, Elina Gonçalves da Fonte; NORONHA, Eduardo Garuti. A complexidade da normatização do trabalho no Brasil. In: KREIN, José Dari; CARDOSO JUNIOR, José Celso Pereira Cardoso; BIAVASCHI, Magda de Barros e TEIXEIRA, Marilane Oliveira (Orgs). Regulação do Trabalho e Instituiçóes Públicas. São Paulo: Fundação Perseu Abramo, 2013, p. 65-72. 
PREFEITURA DA CIDADE DE SÃO PAULO. Lei n. 13.113, 16 de março de 2001. Dispóe sobre a proibição do uso de materiais, elementos construtivos e equipamentos da construção civil constituídos de amianto. DOM,17/03/2001, p. 1. Disponível em: $<$ https://leismunicipais.com.br/a/sp/s/sao-paulo/lei-ordinaria/2001/1311/13113/lei-ordinaria-n13113-2001-dispoe-sobre-a-proibicao-do-uso-de-materiais-elementos-construtivos-e-equipamentosda-construcao-civil-constituidos-de-amianto>. Acesso em 20 nov. 2017.

SECRETARIA NACIONAL DE RELAÇÓES DE TRABALHO E DEPARTAMENTO INTERSINDICAL DE ESTATÍSTICA E ESTUDOS SOCIOECONÔMICOS. Terceirização e desenvolvimento - uma conta que não fecha. São Paulo: Central Única dos Trabalhadores, 2014.

SIEDER, Rachel; SCHJOLDEN, Line; ANGELL, Alan. The judicialization of politics in Latin America. New York: Palgrave MacMillan, 2005.

SILVA, Jeferson Mariano. Jurisdição constitucional em Espanha (1981-1992) e Brasil (1988-1997). 401 f. Tese de Doutorado (Ciência Política). Programa de Pós-Graduação em Ciência Política. UERJ, 2016.

SILVA, Sayonara Grillo Coutinho Leonardo da. Direitos fundamentais, garantismo e direito do trabalho. Revista do TST, v. 77, n. 3, p. 274-292, 2011.

TAYLOR, Matthew. O judiciário e as políticas públicas no Brasil. Dados, v. 50, n. 2, p. 229-257, 2007.

VIANNA, Luiz Werneck; CARVALHO, Maria Alice Rezende de; MELO, Manuel Palacios Cunha; BURGOS, Marcelo Baumann. A judicialização da política e das relaçóes sociais no Brasil. Rio de Janeiro: Revan, 1999.

Texto recebido em 20 de outubro de 2017. Aprovado em 17 de novembro de 2017. 